\title{
HISTORICAL EVENTS ASSOCIATED WITH FALLOUT FROM BRAVO SHOT-OPERATION CASTLE AND 25 Y OF MEDICAL FINDINGS
}

\author{
E. P. Cronkite, R. A. Conard, and V. P. Bond*
}

\begin{abstract}
The events prior to Bravo Shot-Operation Castle that led to a decision not to evacuate the Marshallese prior to testing the thermonuclear bombs are presented as are the actions taken after the fallout incident in evacuating the exposed Marshallese and the military personnel. The initial medical effects (findings during first 6 wk after exposure) are briefly described and are followed by description of long term effects, namely, induction of one case of fatal acute myeloid leukemia and a large number of thyroid tumors (benign and malignant) in addition to hypothyroidism in adults and children and two cases of cretinism. The hypothyroidism and cretinism responded well to administration of oral thyroxine. During the first $25 \mathrm{y}$, there was also much unrest and political agitation initiated by exposed and unexposed Marshallese who were very unhappy as a result of relocation and inability to return to their homelands and feeling that all illness and deaths were due to the mysterious radiation, which they understandably did not understand. The difficulties in part were ameliorated by financial aid from the U.S. Congress. In view of one of us (EPC), no one agency or person in the U.S. Government was willing to take the responsibility for care of the Marshallese and its financing. The exposed and nonexposed Marshallese had their lifestyle changed, some of their homelands made uninhabitable for several years and could aptly be called "nuclear nomads," an expression coined by others.
\end{abstract}

Health Phys. 73(1):176-186; 1997

Key words: Marshall Islands; fallout; thyroid; health effects

\section{INTRODUCTION}

The pURPose of this paper is to provide background information on who of the Marshallese were not evacuated prior to Operation Castle, an operation for testing of thermonuclear bombs in the Pacific Proving Grounds. In addition, we outline the response of the Commander Joint Task Force Seven (CJTF7) to the exposure of natives and military personnel to large amounts of fallout radiation and describe how both were evacuated. When the CJTF7 requested the Atomic Energy Commission

* Medical Department, Brookhaven National Laboratory, Upton, NY 11973.

(Manuscript received 12 March 1997; revised manuscript received 24 March 1997, accepted 11 April 1997)

0017-9078/97/\$3.00/0

Copyright @ 1997 Health Physics Society
(AEC) and Department of Defense to send a medical team to study and take care of the exposed Marshallese and military personnel, they turned to the Navy Medical Department and Armed Forces Special Weapons Project (AFSWP) for help since both had been concerned with study of biomedical effects of radiation at bomb test sites in Nevada and the Pacific. The three of us EPC, RAC and VPB had been associated with several atomic weapons tests from the first (Operation Crossroads). There were no plans for biomedical studies in Operation Castle and hence no qualified medical personnel were available within the Joint Task Force-7 (JTF-7) to perform such on the accidental casualties.

Cronkite, Conard and Bond had been actively pursuing radiobiological research at the Naval Medical Research Institute (NMRI) (EPC and RAC) and VPB at the U.S. Naval Radiological Defense Laboratory (USNRDL). All research had been directed toward potential therapy of acute radiation injury in human beings. In addition, EPC had reviewed the reports of the Atomic Bomb Casualty Commission to learn the mechanism of fatal irradiation injury in the Japanese casualties. Accordingly, all three were familiar with the various syndromes that could be produced by exposure to whole body irradiation and had the necessary security clearances for entry into the Pacific Proving Ground.

It is difficult to provide references since data or comments are based on voluminous Commander Joint Task Force operational orders and Radiological Safety Reports that are only available through the Defense Nuclear Agency, Washington, DC. These are listed in part in the references.

\section{Prologue to Bravo Shot of Operation Castle}

Joint Task Force Seven (JTF-7) Commander Lt. General Clarkson. During previous atomic tests, natives were protected by temporary relocations. Gordon Dunning, AEC Division Biology and Medicine (DBM) stated "the main objection to evacuation is the high cost and the logistic problems presented in supporting such an operation." CJTF-7 concurred emphasizing the military financial austerity for 1954 and the lack of ships and aircraft. If evacuation became necessary, the security ships of JTF-7 would be required to accomplish this upon request of Commander in chief of Pacific Fleet 
(CINCPACIFLT) who was designated to be responsible for safety of people outside of the designated test area by Commander in chief Pacific (CINCPAC) (Defense Nuclear Agency 1985).

\section{Pretest}

The maximum permissible exposure (MPE) for task force personnel was set at $3.9 \mathrm{R}$ accumulating $0.3 \mathrm{R}$ $\mathrm{wk}^{-1}$ for $13 \mathrm{wk}$. All exposure was assumed to be gamma radiation. Key personnel were anticipated to exceed 3.9 $\mathrm{R}$. With the concurrence of the Surgeon Generals (SG) of the Army, Navy, Air Force and the Director, DBM AEC (John Bugher) the MPE for special personnel was set at $20 \mathrm{R}$, a dose considered acceptable for the natives (Defense Nuclear Agency 1985).

CJTF-7 was responsible for safety of Task Force (TF) personnel and was directed to advise CINCPAC about special hazards and danger areas within the purview of CINCPAC and outside of the area for which CJTF-7 was responsible. CINCPAC directed CINCPACFLT (13 January 1954) to assume complete responsibility for safety matters for CINCPAC and to take such actions as necessary to provide for the safety of all units and populated areas of the Pacific except those areas for which JTF-7 was responsible (Command Joint Task Force).

Dosimeters were not placed on the atolls occupied by Marshallese to determine the exposure rate nor were film badges or integrating dosimeters used to determine the total exposure (Defense Nuclear Agency 1985).

\section{Analyses and recommendations made for future tests after Bravo}

The BRAVO shot was estimated to explode at $6 \pm 2$ MT. It detonated at 15 \pm 2 MT (Defense Nuclear Agency 1985). It was fired on land in Bikini atoll near NAMU.

The bulk of the native populations within 500 nautical miles (NM) resided in the southeast quadrant out of fallout area. The clouds with radioactive particles passed over Ailinginae, Rongelap, Utirik, and Ailuk depositing fallout and irradiating the persons below from the radioactive cloud (cloud shine).

The evacuation after Bravo was considered sound by the Task Force, was well executed, and could serve as a model for future tests.

The following features would enhance any future evacuation:

1. Provide ship captains that may be involved in evacuation with detailed maps of all Northern Atolls;

2. Inform native populations of upcoming tests so they would be prepared for unusual phenomena (intense light, noise, and shock wave and fallout);

3. Advise natives to return promptly to home islands if any unusual phenomena are observed so that all will be concentrated in one place for prompt evacuation; and

4. Provide dosimeters recording dose rate and integrating (film) for inhabited areas so that the dose from fallout and from cloud shine will be known.
The reasons for not evacuating natives were:

1. Economy imposed by reduction in military budget for FY 1954;

2. The notion that fallout would not be a problem was based on Operation Ivy experience (first thermonuclear explosions); and

3. Inadequate ships and aircraft to relocate Marshallese to safe areas.

\section{The "Bravo" accident}

A serious fallout accident occurred following the first test, "Bravo," a thermonuclear device at Bikini Atoll on 1 March 1954. In spite of some uncertainty about the weather, the device was detonated at 6 a.m. An unexpected shift in winds resulted in fallout on Marshallese on Rongelap, Ailinginae, Utirik and Ailuk Atolls, American servicemen on Rongerik Atoll, and Japanese fishermen on The Lucky Dragon. Several naval vessels, 30 miles east of Bikini, unexpectedly encountered fallout with white flakes falling on the decks of the ships. Flank speed retreat was ordered; the automatic wash down systems removed substantial amounts of fallout. Crews remained below deck minimizing exposure. Later several sailors developed mild radiation burns of the skin (Defense Nuclear Agency 1985).

The extensiveness and amount of the fallout emerged slowly because of confusing and overlapping events. Difficulties were encountered with the cloudtracking planes. There was confusion about the radiological situation on Rongerik atoll. The men on Rongerik saw a mist $4 \mathrm{~h}$ after the blast. Seven hours later, the needle of a radiation-measuring instrument went off scale at $100 \mathrm{mR} \mathrm{h}^{-1}$. The next day a radiological safety officer arrived by air. Due to the high levels of radiation, he evacuated personnel and recommended immediate surveys of Rongelap and Utirik. Radiation levels on Rongelap and Utirik resulted in evacuation of the people. Ailuk Atoll had measurable levels, but it was decided not to evacuate the 400 people on that atoll (Defense Nuclear Agency 1985).

The Fukuru Maru (Lucky Dragon), with a crew of 23 men, was about 80 miles east of Bikini. The fishermen saw the detonation from their ship. Soon a snow-like fallout covered the deck and stuck to the exposed portions of their bodies. The crew experienced nausea and vomiting for $24 \mathrm{~h}$. The ship's captain decided to return to Japan, arriving 2 wk later. By this time, skin burns were developing and the crew was put into hospitals.

The Marshallese inhabitants of Rongelap saw the flash of the detonation describing it as "like the sun rising in the west" followed minutes later by a blast wave. In early morning a snowlike material fell for several hours covering the ground and adhering to the body. Water in the cisterns was said to turn yellowish. The health aide advised against drinking water but many people did. During the first two days several became nauseated, a few vomited and had diarrhea. On 3 March, the people on 
Rongelap and Ailinginae were evacuated by plane and ship to Kwajalein (Defense Nuclear Agency 1985).

The 159 people on Utirik Atoll saw the flash of the detonation in the west and felt the blast wave. Fallout was not seen on Utirik. It was estimated that the fallout began at about 4:00 a.m. on 2 March (about $22 \mathrm{~h}$ after the detonation) and continued for about 4-5 h. The Utirik people did not have any cutaneous or GI symptoms. On 4 March, the Utirik people were evacuated by Navy destroyer to Kwajalein (Defense Nuclear Agency 1985).

\section{Establishment of the initial medical program}

On or about 4 March, one of us (EPC) was ordered to report immediately to the Navy Surgeon General's Office, Washington, DC. Already present were Shields Warren, M.D., past Director of DBM-AEC; John Bugher, M.D., ${ }^{\dagger}$ the present Director, DBM-AEC; Charles Dunham, M.D. ${ }^{{ }^{+}}$Director Medical Program and later Director of DBM; representatives of Armed Forces Special Weapons Program (AFSWP) and others.

The CJTF-7 had requested the Department of Defense and the AEC to organize a medical team to take care of the exposed natives and military personnel and to study the effects. The assistance of the Medical Department of the USN was requested and given promptly by Surgeon General Lamont-Pugh. The situation was described. EPC was given verbal orders to organize a team in conjunction with AFSWP and to be ready to depart within $48 \mathrm{~h}$ with necessary laboratory equipment. The services of V.P. Bond, M.D., Ph.D., USNRDL, were requested as were the services of R.A. Conard, Cdr. MC USN, two other Medical Officers and two Medical Service Corp Officers. Several enlisted personnel from NMRI and U.S. Naval Radiological Defense Lab (USNRDL) with appropriate security clearance were assigned to the team. A total of 25 persons was airlifted to Kwajalein (Conard et al. 1955).

It was believed that the dose to the Marshallese was sublethal (Cronkite et al. 1955). However, in addition to the medical team, second echelon help was identified. For example, a preventative medicine unit of the CINCPACFLT was alerted for possible bacteriological studies along with additional clinicians and nurses in case their services were needed. Rear Admiral Bartholomew Hogan, MC USN PACFLT Medical Officer, met with the medical team on landing at Oahu and promised support of medical facilities of the Pacific Fleet. With the preceding planning and backup, it was felt that medical problems that arose could be handled at Kwajalein.

\footnotetext{
${ }^{\dagger}$ Logistic support was complex-organization of medical teams, shipment of medical supplies and equipment, travel arrangements, setting up examination facilities on Rongelap and Utirik Islands, etc. Travel in the islands in the early years was by U.S. Navy and Trust Territory cargo ships. Later, a small ship with examination facilities was acquired. The U.S. presence in the islands brought in money and jobs, and since many people from Rongelap and Utirik migrated to the district centers at Ebeye and Majuro, additional examining facilities had to be set up in these centers.
}

En route Oahu to Kwajalein the physicians of the medical team discussed management of the exposed persons. They unanimously decided that we'd listen to estimates of the exposure dose of radiation but management of the casualties would be guided solely by developing signs and symptoms.

The medical team arrived at Kwajalein on 8 March 1954. The Commander U.S. Naval Station Kwajalein gave immediate support and within $24 \mathrm{~h}$ a functioning laboratory and clinic were available adjacent to housing for the natives.

On arrival at Kwajalein, a "letter of instruction" was given to EPC from Col. Gilbert, USAF establishing project 4.1 with EPC as project officer and requiring that all requests for support beyond that locally available be directed to Commander Task Group 7.1 Attn Commander Task Unit 13 placing a line officer between the medical team, the SG's and DBM AEC. Project 4.1 was classified Secret Restricted Data.

\section{Summary of clinical observations}

Full descriptions are published (Cronkite et al. 1955, 1956).

\section{Nature of the event and exposed groups}

The fallout consisted of fission products and included radioactivity adherent to flakes of $\mathrm{Ca} 0$ that fell on the inhabited islands of Rongelap, Ailinginae, and Rongerik. $\mathrm{Ca} 0$ was formed by incineration of coral (largely $\left.\mathrm{CaCO}_{3}\right)($ Cronkite et al. 1956). The flakes resembled snow on Rongelap, mist on Rongerik, and was invisible on Utirik. The flakes of $\mathrm{Ca} 0$ adhered to the skin, hair, trees, and buildings. The exposure of the individuals was from material adherent to the skin, the radioactive material on the ground, trees, and buildings. There was also an unknown increment of gamma radiation from the radioactive cloud as it passed by (cloud shine). The material adherent to skin and hair irradiated the skin and hair follicles with an unknown amount of mixed beta and gamma irradiation. The military personnel aware of the hazard, changed clothes, bathed and stayed inside the building, thus receiving a lesser dose to skin and deep tissues.

The Marshallese and Servicemen had been evacuated by air and ship to Kwajalein where the radioactive contamination of skin and clothes was still evident despite shipboard decontamination. Repeated washing of skin and hair was continued. Decontamination of hair of females was particularly difficult because of the heavy coconut oil hair dressing they used. On nearby Ailuk Atoll, about 400 natives with about same or lesser dose as Utirik were not evacuated.

\section{Whole body gamma dose}

Dose rate was determined at $3 \mathrm{ft}$ above ground on Rongelap, Ailinginae and Rongerik several days after evacuation. Making assumptions about arrival time of radioactive cloud the doses were calculated for Rongelap and Ailinginae (Cronkite et al. 1956). On Rongerik the 
arrival time was documented by a recording dosimeter. The dose rate was diminished by the decay of the short-lived isotopes. The dose from the cloud shine remains unknown; however, the consistency of the calculated doses with the doses that were measured by film in refrigerators on Rongerik increases the reliability of the dose to personnel on the atolls.

The external doses are listed in Table 1.

\section{Characteristics of the gamma radiation and tissue dose distribution}

The fallout on the ground constituted a large planar source. Spectrometric data of the mixed fission products and the degradation by Compton scattering in air resulted in a radiation field with maxima at 100,700 and 1,500 $\mathrm{keV}$. The total exposure is the sum of partial doses from each energy region. This, plus the planar source (radiation coming from all directions), resulted in a relatively high dose to the first $1-3 \mathrm{~cm}$ of tissue equivalent material, perhaps 8 times the midline dose. The absorbed dose throughout the rest of a tissue equivalent phantom man was quite constant (Cronkite et al. 1956).

The fallout occurred in a cigar-shaped pattern. In the easterly direction the $8 \mathrm{~Gy}$ isodose curve extended about 140 miles, 5 Gy about 160 miles, 3 Gy about 190 miles, and 2 Gy about 220 miles. The north-south distance for 2 Gy was roughly 40 miles with shorter distances for the higher isodose curves. A few miles north of the 2 Gy line might have been lethal. These doses are estimates of what would have accumulated over a 48 -h period without shielding (Cronkite et al. 1956).

\section{Clinical observations and management}

Twenty eight percent of the Rongelapese, $20 \%$ of the Ailinginaeans and $5 \%$ of the military personnel experienced itching and burning of the skin. The natives on Utirik had no cutaneous symptoms.

During exposure there was burning of the skin, eyes and lacrimation that subsided (Cronkite et al. 1956). About 2 wk after exposure, itching, burning and pain became evident in areas of skin not protected by clothing. There were no constitutional symptoms associated with developing skin lesions. The sequence of signs and symptoms were subsidence of early symptoms, develop- ment of black pigmented areas, and increase in size of the lesions. Desquamation of the epithelium resulted in large depigmented areas. In some lesions ulcers developed and some became infected. Epilation, spotty in nature, occurred in some individuals. Hair regrew with normal color and texture. In one older man it regrew somewhat sparsely. Biopsies of lesions showed the typical appearance of radiation injury. The lesions healed. After healing, depigmented scars, particularly on the feet, were evident. The infected ulcers were treated successfully with antibiotic ointments. Details of skin lesions with color photographs are published (Cronkite et al. 1956).

The skin lesions were minimized in the military personnel who bathed, changed clothes and took shelter in aluminum buildings. Children who went wading had fewer and less severe burns of the feet. A single layer of cotton clothing gave almost complete protection. The legs and feet also received additional exposure from beta radiation from fallout on the ground.

\section{Early constitutional symptoms}

About two-thirds of Rongelap group were nauseated for $2 \mathrm{~d}$. About one-tenth vomited and had diarrhea. These symptoms suggested significant radiation exposure (Cronkite et al. 1956).

There were no GI symptoms in military personnel or the natives from Utirik.

\section{Hematologic observations}

Blood counts (neutrophil, platelet and lymphocytes) are sensitive indicators of marrow suppression. Extensive simple hematologic studies were performed. Since there were no prior hematologic studies on the exposed Marshallese or any comparable group, it was necessary to establish a control group of non-exposed Marshallese of same age and sex distribution for comparative purposes.

\section{Neutrophil count}

The absolute count of all age groups fell during the second week to about $70-80 \%$ of the comparison population (Cronkite et al. 1956). Following this initial depression, the counts fluctuated around the comparison group until $30 \mathrm{~d}$ after exposure and then progressively decreased with minima being reached at $45 \mathrm{~d}$ after

Table 1. Doses to the exposed personnel and Marshallese.

\begin{tabular}{|c|c|c|c|c|c|}
\hline & $\begin{array}{c}\text { Total } \\
\text { exposed }\end{array}$ & $\begin{array}{l}\text { Arrival time } \\
\text { fallout } \\
\text { hours }\end{array}$ & $\begin{array}{c}\text { Evacuation } \\
\text { hours }\end{array}$ & Dose rate & $\begin{array}{l}\text { Total gamma } \\
\text { dose in air } \\
\text { (Gy) }\end{array}$ \\
\hline Rongelap & 67 & $4-6$ & $50-51$ & $\begin{array}{l}375 \mathrm{mR} \mathrm{h}^{-1} \\
\text { at } 7 \mathrm{~d}\end{array}$ & 1.9 \\
\hline Ailinginae & 18 & $4-6$ & 58 & $\begin{array}{l}100 \mathrm{mR} \mathrm{h}^{-1} \\
\text { at } 9 \mathrm{~d}\end{array}$ & 1.1 \\
\hline $\begin{array}{c}\text { Rongerik U.S. } \\
\text { Personnel }\end{array}$ & 28 & 6.8 & $28.5-34$ & $\begin{array}{l}280 \mathrm{mR} \mathrm{h}^{-1} \\
\text { at } 9 \mathrm{~d}\end{array}$ & 0.78 \\
\hline Utirik & 167 & 22 & $55-78$ & $\begin{array}{c}40 \mathrm{mR} \mathrm{h}^{-1} \\
\text { at } 8 \mathrm{~d}\end{array}$ & 0.11 \\
\hline Marshallese Control & 117 & & & & \\
\hline American Control & 105 & & & & \\
\hline
\end{tabular}


exposure. The depression of neutrophils was greater in children less than $5 \mathrm{y}$ of age than in older children and adults (Cronkite et al. 1956). At 6 mo and $1 \mathrm{y}$ after exposure, the neutrophil counts were close to the control population.

\section{Further clinical observations and blood counts}

Between 33 and $43 \mathrm{~d}$ after exposure the absolute neutrophil counts of Rongelapese were less than 1,000 $\mathrm{mm}^{-3}$. The lowest count was $700 \mathrm{~mm}^{-3}$. During this interval the question of prophylactic antibiotics was considered. The administration of antibiotics was not commenced because

- Individuals were seen daily. Temperatures were taken. If an infection were to develop, it would be discovered early and therapy commenced.

- Premature administration of antibiotics might obscure infectious processes and might lead to development of drug resistant commensal bacteria in individuals with lowered resistance to infection.

- There was no useful knowledge in 1954 of the number of granulocytes below which infections from commensal organisms might develop.

The clinical picture of the Rongelapese was significantly different from the Japanese exposed to atomic bombs. In Japan, the radiation was delivered in a short burst. The Marshallese were exposed over several hours with a decaying dose rate. Their granulocyte counts decreased slowly to about one-fourth of the normal values. Immature granulocytes were observed in the peripheral blood suggesting regeneration of the bone marrow. In the Japanese whose neutrophil counts fell precipitously to low levels, infections with septicemia developed with a high mortality.

During the fourth and fifth week after exposure, an epidemic of upper respiratory infections (URI) occurred in all Marshallese with fever and a purulent nasal and tracheal discharge for about $10 \mathrm{~d}$. A similar URI occurred in the control population and Medical Team (Cronkite et al. 1956).

\section{Platelet counts and hemorrhagic diathesis}

In 11 individuals the platelets fell between 35,000 to $65,000 \mathrm{~mm}^{-3}$. Individuals with platelets less than $100,000 \mathrm{~mm}^{-3}$ were examined daily for retinal bleeding, cutaneous petechiae, hematuria (microscopic), and women were questioned about excessive menstruation. At the nadir of platelet counts, two women had excessive bleeding. It subsided spontaneously (Cronkite et al. 1956).

The platelet counts were very slow (several years) in reaching the average of the control population (Conard 1992; Cronkite et al. 1956).

\section{Pregnancy}

Four Rongelapese were pregnant; two in first trimester, one in second, and one in third. In the Ailinginae group, one woman was in second trimester. The pregnant women had a significant thrombopenia. There was no vaginal bleeding. One baby was born dead; the others were normal. Whether irradiation was responsible for the stillbirth is unknown.

\section{Lymphocyte counts}

By $3 \mathrm{~d}$ after exposure, the lymphocyte counts were $50 \%$ of the comparison group. The decrease observed in children less than $5 \mathrm{y}$ of age was more pronounced. The lymphopenia persisted through the initial observation and was still present at $6 \mathrm{mo}, 12 \mathrm{mo}$, and for several years after exposure (Conard 1992; Cronkite et al. 1995).

\section{Platelets}

The maximum depression in platelet counts occurred at 28 to $30 \mathrm{~d}$ after exposure. The children less than $10 \mathrm{y}$ of age had a greater percentage drop. The platelet levels commenced to recover $30 \mathrm{~d}$ after exposure, attaining a maximum on day 45 with a secondary drop and leveling off for the remainder of the post exposure period. There was a very slow recovery in average platelet counts to that of the control population (Conard 1992; Cronkite et al. 1995).

\section{Internal deposition of radioactive materials: Early observations}

The amount of internal exposure was derived by radiochemical urinalyses carried out beginning at about 2 wk after exposure. Only radioactive strontium $\left({ }^{90} \mathrm{Sr}\right)$ and iodine $\left({ }^{131} \mathrm{I}\right)$ were near the maximum permissible levels. No effects of any of these absorbed elements, except for radioiodine have been detected in the Marshallese people. The details of early internal contamination are published (Cronkite et al. 1956).

Since thyroid tumors developed and there was evidence of hypothyroidism, reevaluation of the thyroid dose was needed. It was based on the distribution of the iodine family of radioisotopes in fission products, their decay rates, arrival of fallout, time on the contaminated atolls, thyroid size as a function of age, the excretion of ${ }^{131} \mathrm{I}$ in 24 -h urine samples at $17 \mathrm{~d}$, the biological half-life and the measured ${ }^{131} \mathrm{I}$ in air samples. The major route of radioisotopes into the body was via ingestion. Inhalation was of minor importance. Details have been published by Lessard et al. (1985). The doses are shown in Table 2 for age and island groups.

\section{Post Bravo care and responsibility for fallout casualties}

CJTF-7 was responsible for temporary care and disposition. It was decided by higher authority to transfer the military personnel to Tripler General Hospital in Hawaii, and then they were returned to duty without any follow-up studies planned. CINCPACFLT was assigned responsibility for restoration of atolls with AEC assistance and for return of inhabitants at proper time and the Trust Territory Hi Com (Department of Interior) for routine welfare and medical care. 
Table 2. Dose estimates (Gy) to the thyroid (Lessard et al. 1985).

\begin{tabular}{clcc}
\hline Group & Age & $\begin{array}{c}\text { External } \\
\text { dose }\end{array}$ & $\begin{array}{c}\text { Thyroid dose } \\
\text { (ave-max) } \\
\text { (Gy) }\end{array}$ \\
\hline $\begin{array}{c}\text { Rongelap } \\
\text { (67 people) }\end{array}$ & $1 \mathrm{y}$ & 1.9 & $50-200$ \\
& $9 \mathrm{y}$ & 1.9 & $2-8$ \\
Ailinginae & Adult & & $1-4$ \\
(18 people) & $1 \mathrm{y}$ & 1.1 & $13-52$ \\
& $9 \mathrm{y}$ & 1.1 & $5.4-22$ \\
Utirik & Adult & & $2.8-11.2$ \\
(167 people) & $1 \mathrm{y}$ & 0.1 & $6.7-27$ \\
& $9 \mathrm{y}$ & 0.1 & $3.0-12.0$ \\
& Adult & 0.1 & $1.5-6.0$ \\
\hline
\end{tabular}

On 24 April 1954, the project 4.1 medical team made detailed recommendations for life long observations to CJTF-7. The project 4.1 team did not visualize the development of thyroid problems. In 1954 there was no clear cut evidence of susceptibility of the thyroid to radiation effects other than ablation by high doses.

On 12-13 July 1954, a conference on "Long Term Surveys and Studies of Marshall Islands" was convened at USAEC, Washington, DC, at offices of John Bugher, Director DBM for planning future studies on the possible hazards of living on the contaminated atolls and care of the exposed Marshallese. The conference was classified Secret Restricted Data. It was chaired by John Bugher, M.D., Director DBM-AEC. In his opening statement Bugher emphasized that the U.S. holds the Pacific Islands Trust Territory (TT) including the Marshall Islands's in trust. The mandate was administered by a trusteeship under the Department of Interior. The U.S. held the right to withdraw such land as might be necessary for strategic and security purposes but beyond that "to administer the whole area for the benefit of the people concerned".

Bugher expressed his pleasure at the apparent recovery of the exposed Marshallese but had reservation in respect to possible development of carcinoma in the beta burns of skin. It was concluded that there should be regular examinations of the Marshallese for 1) cancer, 2) cataracts, 3) growth and development, 4) general health, and 5) study of flora and fauna for radioactivity, uptake into food chain, and that the medical studies should be separate from the studies on flora and fauna. Bugher, in a prelude to development of plans and identification of personnel emphasized that 1) there are groups with authority without capability and other groups with capability without authority; 2) the Marshallese are not U.S. citizens; and 3) the Marshallese reside in a place that is not American territory. The U.S. under the UN Trusteeship is the Governing Authority (GA). The U.S. does not have sovereignty.

The GA delegated the Department of Interior as the administrative body with whom the Marshallese would deal through the Hi Com TT. The Hi Com did not have the scientific staff or the logistic resources to do the things that must be done.

The AEC accepted the responsibility for the continuing studies and care of the exposed Marshallese. The $\mathrm{AEC}$ has in part the scientific resources but does not have the necessary logistic support in the Pacific area.

Bugher clearly perceived the problems then present and that would emerge in the future with clairvoyance. No one organization in the U.S. had the responsibility, the authority, and the capability to do what the U.S. was mandated to do by the Trusteeship and was morally obligated to do. As time went on no one organization seemed to wish to see that the U.S. lived up to their obligations.

Bugher hoped that the same individuals and institutions involved with the initial event would be able to continue over the succeeding years, namely personnel at NMRI and USNRDL recognizing that personnel would change with time.

In a letter to Admiral Pugh (SG USN), Bugher solicited help and outlined the requirements for the continuing observations on the exposed Marshallese and their control population. At unspecified but regular intervals, physical exams, interval history, hematologic studies, search for cancer and leukemia, cataracts, growth of children, health of newborn and studies on internal deposition of radioisotopes in the exposed persons should be performed.

Financial responsibility would be assumed by DBM-AEC. The SG USN concurred and CINCPAC gave unreserved backing. The TT was happy with this relationship.

It was agreed that V. P. Bond of USNRDL would take a team of his selection for a 6-mo survey and that $E$. $P$. Cronkite would do the same for a 12-mo survey from NMRI in March 1955.

Long term plans were made for continuing medical surveys involving USNRDL, NMRI, USA, and USAF personnel. These plans were altered by the acceptance of Cronkite's request for resignation from the USN and employment in the Medical Department, Brookhaven National Laboratory, effective 1 October 1954. Bond also relocated from USNRDL to BNL in December 1954. DBM-AEC then decided to transfer responsibility for organizing continued studies to the Medical Department, BNL, in a letter from Bugher to AUI Trustees. He requested that Medical Department, BNL, assume the responsibility for the continuing medical surveillance of the Marshallese.

The 6- and 12-mo surveys showed the Marshallese to be in good general health. There was scarring from the beta burns in some individuals. There was no evidence of cutaneous cancer or hyperkeratosis.

In 1955, R. A. Conard's resignation from the USN was accepted and he accepted an appointment in Medical Department, BNL, with responsibility for directing the continuing medical surveillance of the exposed Marshallese and their comparison population. The responsibility 
for general medical care of other Marshallese was that of the TT (Department of Interior).

In 1956 July, an unclassified account of the effects of radiation on the Marshallese was published by the US Government Printing Office (Cronkite et al. 1956). It was preceded by publication of a short report in the Journal of American Medical Association (JAMA) (Cronkite et al. 1955).

\section{Events Connected with Evacuation of Marshallese}

Bishop Feeney S-J said "the people on Likiep were greatly excited by the light and the blast wave which arrived about $30 \mathrm{~min}$ after the light flash. Church attendance was greatly stimulated on the day of the test." (Defense Nuclear Agency 1985)

As a result of a high dose rate $\left(375 \mathrm{mR} \mathrm{h}^{-1}\right)$ on Rongelap Island, evacuation was considered necessary. After a TT official requested evacuation it was accomplished by air and sea. Sixteen sick and elderly were removed by air and the remainder by ship. Decontamination by bathing and laundering was pursued aboard ship.

The ship proceeded to Ailinginae and picked up 18 Marshallese. Searches were made of other islands to be certain no Marshallese were left behind.

The U.S.S. Phillip arrived at Kwajalein on 4 March at 8:30 a.m., and the Marshallese were disembarked and taken to the USN Dispensary.

\section{Evacuation of Utirik}

Orders received by USS Renshaw on 3 March 1954 at dawn while on patrol north of Enewetak. Set course and speed to arrive at Utirik daylight of 4 March. Arrived at 6:30 a.m. on 4 March 1954. Fortunately the weather was good with light wind and moderate swells. At 7:30 a.m., the ship hove to about 500 yards south of Utirik Island on which all the natives were reported to live. TT officials had not arrived. The $\mathrm{CO}$ proceeded to organize the evacuation awaiting arrival of TT officials and interpreters.

At 7:40 a.m., the gig (26 ft MWB) was launched with beach party aboard. This team was to get ashore, organize the natives for evacuation and locate the best place and means for evacuation.

The team surveyed the village and collected water samples from wells. The water had low radiation levels probably due to roofs over each reservoir. The radiation levels varied from $100 \mathrm{mR}$ to $160 \mathrm{mR} \mathrm{h}^{-}$.

The TT representative arrived by plane. After being apprised of the situation, it was decided to evacuate the natives but to leave the livestock. A life raft was brought in to shuttle people from shore over the reef to a MWB waiting outside the reef. Women, children, and the elderly were first shuttled out to the MWB's, with men last. The skill of the natives and their willingness to help proved invaluable in getting across the reef. All natives were aboard and in their assigned quarters by 12:00 p.m. There were 47 men, 55 women and 52 children under 16 ( 26 boys and 26 girls). At 1:00 p.m., ship was secured and course was set for Kwajalein. The natives were monitored as they came aboard and had an average of about $7 \mathrm{mR} \mathrm{h}^{-1}$, substantially less than the average of 20 $\mathrm{mR} \mathrm{h} \mathrm{h}^{-1}$ on the beach. Transit through the surf apparently washed off a substantial amount of radioactivity.

Natives on Ailuk (about 400) were not evacuated for reasons discussed earlier.

\section{Long-term follow up}

Following the initial examinations, the exposed people of Rongelap including the Control population were examined at Majuro Atoll by a medical team from BNL headed by Conard who continued studies until his retirement 25 y later in 1979.

\section{Examination schedules}

The lack of significant findings during the first $2 \mathrm{y}$ was encouraging. However, in view of studies of the Japanese exposed to the atomic bombs at Hiroshima and Nagasaki and of other irradiated populations, the exposed Marshallese were at greater than normal risk of late effects, such as leukemia and cancer. Therefore, it was recommended that annual examinations of the Rongelap people be continued indefinitely. In view of the small radiation exposure of the Utirik population, it was considered that examinations every 3 y would be adequate. The AEC approved and, with the concurrence of the TT, asked BNL to continue the examinations jointly with the TT.

Conard at BNL was asked to head up the program. It was understood that the Trust Territory would be responsible for the general health care, whereas the AEC mandate limited the medical team to the diagnosis and treatment of radiation effects in the exposed population along with the control population.

It was soon apparent that the general health care was not satisfactory. Therefore, the medical team, within its capability and time limits, expanded efforts to include many other conditions. Later, at the requests of the inhabitants of Rongelap and Utirik, the entire population on the islands was examined. When thyroid nodules developed on Utirik, annual examinations commenced.

Beginning in 1971 for about $10 \mathrm{y}$, a physician from BNL was stationed in the islands to monitor the thyroid treatment program and assist in follow-up care of the exposed Marshallese.

Conard retired in 1979. The surveys of 1980-1981 were headed by Cronkite and Pratt. From 1981-1990, the program was headed by Adams and since 1990 by Howard.

The examinations have continued on an annual (later semi-annual) basis. By 1957, radiological surveys indicated that Rongelap was safe for habitation. A new village was built and the people returned. Examinations were conducted there until 1985 when local politicians decided the island was not safe and the people were again evacuated to a small island in Kwajalein Atoll and the examinations have continued there since then. 
Outstanding physicians in many specialties and subspecialties and technicians from the United States participated in the examinations, including endocrinologists specializing in thyroid problems. They provided extremely important diagnostic, therapeutic, and technical capabilities. Equally important has been the participation of a large number of medical personnel (practitioners, technicians, health aides, and nurses) from the Health Services of the Marshall Islands who contributed in carrying out the examinations, obtaining medical histories, and in acting as interpreters.

\section{Problems associated with the examinations}

Before presenting the late medical findings, some of the problems affecting the examinations are pertinent.

Carrying out the examinations in these distant islands was a complex undertaking and could not have succeeded without the support of many government agencies, e.g., Department of Energy, Department of Interior, Department of Defense and authorities in the Marshall Islands. ${ }^{\dagger}$

The medical teams were faced with the medical care of people with different backgrounds, lifestyles, customs and language. The language barrier made it difficult to communicate with people even with the Marshallese interpreters. Efforts to help the people understand the need for and results of the examinations and the effects of radiation exposure were disappointing. They were afraid of this unseen, unfelt, "poisonous powder" and its effect, and this became a strong psychological factor. They continued to believe that every ailment and every death was somehow related to radiation exposure.

It is understandable that with the disruption of their lives, the development of radiation effects, and the contamination of their islands, there was increasing bitterness towards the United States about the accident and, justifiably, increasing demands for compensation.

Unexpectedly in the 1970's, local politicians and lawyers representing the people and certain Japanese groups instigated actions that concerned the medical team. In 1972 the medical team after arrival at Rongelap had to cancel the examinations due to political interference. ${ }^{\ddagger}$

Following this difficult period, it was encouraging that there ensued a marked improvement in attitude toward the program. There were several possible reasons

\footnotetext{
The criticisms increased and the years 1972 to about 1977 were troublesome. Unexpectedly, the Japanese anti-A and H-bomb groups became involved with the Marshallese politicians in criticizing the way the fallout victims were being handled. These groups were very active in Japan and created much publicity concerning the fallout exposure of the Japanese fishermen on the Lucky Dragon. The Marshallese politicians were greatly angered when the Trust Territory Government refused to allow a Japanese group that they had invited to visit Rongelap to examine the exposed people and the group had to return to Japan. This action precipitated a cascade of events: the abortion of the 1972 medical examinations after the team had arrived at Rongelap due to political interference; the formation of a special investigative committee on Rongelap and Utirik by the Congress of Micronesia with arrangements for medical observers to accompany the examinations.
}

for this: the favorable report of the medical observers to the Congress of Micronesia on the conduct of the examinations; efforts to increase communication with the people about the effects of radiation and the objectives of the program, increased efforts to expand primary health care and, last but not least, the increased response of the United States in compensation settlements. ${ }^{\S}$

\section{Miscellaneous late findings}

Examinations of the exposed Rongelap people at 6 mo showed that they largely had recovered from the acute effects and were generally in good health. No deaths were attributable to radiation exposure. There was further recovery of the blood elements, though they were not yet up to normal levels.

\section{Stillbirths and miscarriages}

During the first decade after the accident, there were few findings that could definitely be associated with radiation exposure. There was an increase in miscarriages and stillbirths in the exposed Rongelap women, but the numbers were small and it is uncertain if this increase was related to radiation effects (Conard et al. 1980). Based on birth rate, fertility has been about the same in the exposed and in the unexposed groups (Conard et al. 1980).

\section{Eye examinations}

Regular examinations of the eyes, including slitlamp studies for cataracts, have not revealed any radiation-induced effects.

\section{Growth and Development}

Anthropometric measurements (height, weight, osseous maturation, etc.) in exposed Rongelap children and matched unexposed children revealed that beginning a few years after exposure some of the exposed children, particularly boys less than $10 \mathrm{y}$ of age, lagged in growth. Growth deficiencies were result of hypothyroidism and were corrected by thyroxin therapy (Cronkite et al. 1995).

\section{Late effects on skin}

Examination of the skin showed slight scarring and pigment changes in areas of the lesions, and a few benign nevi developed in areas of neck burns in a few people. One skin cancer was found recently in an area of former lesion.

\$ In $1966, \$ 950,000$ were granted the Rongelap (about $\$ 11,000$ per person). In 1974 a "Survivor's Fallout Bill" furnished travel and per diem funds for persons requiring hospitalization. In 1978 compensation was paid to Rongelap individuals with radiation injuries. In 1986, the new Republic of the Marshall Islands and the United States agreed to a "Compact of Free Association" to last for $15 \mathrm{y}$. The United States provided $\$ 750$ million for fiscal support, $\$ 150$ million of which was for claim, including injuries related to nuclear testing. Based on a list of possible radiation-related illnesses, a local Nuclear Claims Tribunal has received numerous claims from individuals throughout the Marshalls. 


\section{Possible genetic effects}

Examination of children born to exposed parent or parents, based on the incidence of gross anomalies, has not revealed evidence of genetically inherited defects. Neel was unable to demonstrate any inherited genetic effects in blood samples from the Marshallese (Conard et al. 1980).

Lisco and Conard (1967) found a number of two break chromosomal aberrations (dicentrics, translocations and a ring form) in cultured lymphocytes in the exposed Rongelap at $10 \mathrm{y}$ after exposure.

\section{Degenerative diseases}

The incidence of degenerative disease (cardiovascular, arthritis, nephrosclerosis) is not greater in the exposed Marshallese as of $25 \mathrm{y}$ after exposure (Conard et al. 1980). Studies of aging, using a battery of nonspecific tests did not reveal evidence of radiation-induced premature aging (Conard et al. 1966).

\section{Thyroid dysfunction}

Diverse thyroid abnormalities were the major late effects. First nodules appeared in a 12-y-old girl 9 y after exposure. About one-third of exposed Rongelap developed thyroid abnormalities, the largest incidence was in children exposed when less than $10 \mathrm{y}$ of age whose small thyroids had a higher dose from same amount of radioactive iodine ingested or inhaled (Lessard et al. 1985).

The relationship of growth retardation in children to hypothyroidism was not appreciated at first since the Marshallese have a high level of iodinated protein in their blood (Robbins et al. 1967). When radioimmuno assays for thyroid hormones became available, the depressed thyroid hormone was detected and replacement therapy commenced with success. Details of thyroid function in the Marshallese adults and children are described in Conard et al. (1980).

In 1966, on the advise of a panel of thyroid experts, the exposed Rongelapese (later the Ailinginae group) were put on lifetime thyroxine replacement therapy in the hope of reducing the development of thyroid tumors. Compliance with the program by the people has not always been satisfactory. The thyroxine treatment has not been completely successful. Some people on therapy developed tumors. The treatment has been most rewarding in promoting normal growth in the children that showed growth retardation.

Surgical removal of the thyroid nodules in both the exposed and control populations was carried out usually in hospitals in the United States. (In a few cases because of age or health, surgery was not done). Metastases to the lymph nodes in the neck had occurred in some cases but distant metastasis was not noted. Recovery from surgery was uncomplicated and no fatalities have occurred related to thyroid cancers.

Hypothyroidism. Hypothyroidism and cretinism were observed. Two infants exposed on Rongelap had estimated doses of 50 to 200 Gy (Lessard et al. 1985). The real dose is more likely close to $50 \mathrm{~Gy}$. When treated with thyroxin, normal growth ensued (Conard et al. 1966; Robbins et al. 1967; Sutow and Conard 1969; Conard et al. 1970).

Two Rongelap children exposed in utero later developed benign thyroid tumors suggesting that radioiodine from the mother may have been partly responsible for the thyroid tumors (Conard et al. 1980).

Thyroid adenomata and cancer. The revised thyroid doses are published in detail (Lessard et al. 1985). Adenomata commenced appearance about $10 \mathrm{y}$ after exposure. The incidence peaked at between 12 and $14 \mathrm{y}$ and declined thereafter to a low incidence. The higher doses also resulted in a shorter latency before appearance. The early adenomata appeared in individuals who had thyroid exposures in range of 0.02-50 Gy whereas later appearing adenomata occurred in people whose thyroid had 2 to $20 \mathrm{~Gy}$. Thyroid cancer occurred in individuals whose thyroid had 2.5-30 Gy. No cancers observed in individuals when thyroids received more than $30 \mathrm{~Gy}$.

Benign adenomata increased in incidence from exposure to $2.5 \mathrm{~Gy}$ or more radiation. Hypothyroidism was observed in individuals whose thyroid received in excess of $54 \mathrm{~Gy}$. There are simply not enough cases to draw any conclusion in respect to a dose effect relationship.

\section{Leukemia}

One case of acute myeloblastic leukemia developed in a boy age $19 \mathrm{y}$, exposed to $1.9 \mathrm{~Gy}$ at $1 \mathrm{y}$ of age. This leukemia was probably due to exposure to radiation. One case of leukemia also occurred in the control population in a male age $63 \mathrm{y}$.

\section{Longevity}

Survival curves for the people exposed on Rongelap, Ailinginae, Utirik and Rongelap unexposed people show there is no significant difference. Actually of those exposed on Rongelap and Ailinginae, there was a slightly higher fraction alive in 1986 (Conard et al. 1992).

\section{Internal deposition of radioactive materials}

The amount of internal exposure was derived by radiochemical urinalyses carried out beginning at about 2 wk after exposure. Only radioactive strontium $\left({ }^{90} \mathrm{Sr}\right)$ and iodine $\left({ }^{131} \mathrm{I}\right)$ were near the maximum permissible levels. Based on later studies, plutonium, a long-lived element, was present in small amounts and well within the federal guidelines. By $6 \mathrm{mo}$, there was barely detectable radioactivity in the urine of the Rongelap people. Table 3 shows the early mean body burden of the Rongelap group for isotopes other than radioiodine.

In view of the extensive later development of thyroid abnormalities (largely from radioiodine exposure), it became apparent that the original doses estimated to this organ were too low; and re-evaluation of the doses received by the Marshallese is shown in Table 2 . The dose from the iodine family of radioisotopes is discussed in detail by Lessard et al. (1985). 
Table 3. Mean body burden of Rongelapese in early period after exposure.

\begin{tabular}{llcl}
\hline \multicolumn{1}{c}{ Radioisotope } & $\begin{array}{c}\mu \mathrm{Ci} \text { at } \\
82 \mathrm{~d}\end{array}$ & $\begin{array}{c}\text { USNRDL } \\
\mu \mathrm{Ci} \text { at } 1 \\
\mathrm{~d}\end{array}$ & $\begin{array}{c}\text { LASL } \mu \mathrm{Ci} \\
\text { at } 1 \mathrm{~d}\end{array}$ \\
\hline${ }^{90} \mathrm{Sr}$ & 0.19 & 1.6 & 2.2 \\
${ }^{140} \mathrm{Ba}$ & 0.021 & 2.7 & 0.34 \\
$\begin{array}{l}\mathrm{Rare} \text { earth group } \\
{ }^{103} \mathrm{Ru}\end{array}$ & 0.03 & 1.9 & - \\
${ }^{45} \mathrm{Ca}$ & - & - & 0.013 \\
\hline
\end{tabular}

\section{Internal deposition of radioisotopes}

In addition to the medical studies, the BNL Medical Team assumed responsibility for personnel monitoring of the Rongelap and Utirik people and the Bikini people who returned to their home island in 1969. In 1978, environmental and personnel monitoring were transferred to the Safety and Environmental Protection Division of BNL.

During the first few years after the Bikini people returned to their islands, the levels of exposure were low. However, by 1978, due to availability of plant foods, there was a sudden increase in whole body levels of ${ }^{137} \mathrm{Cs}$ and ${ }^{90} \mathrm{Sr}$, and the people were evacuated again.

At the time of return of the Rongelap and Utirik people, radioactive elements of concern were cesium $\left({ }^{137} \mathrm{Cs}\right.$, a gamma emitter with a half-life of $\left.30 \mathrm{y}\right)$, strontium $\left({ }^{90} \mathrm{Sr}\right.$, a beta emitter with a half-life of $28 \mathrm{y}$ ), and zinc ${ }^{65} \mathrm{Zn}$, a gamma emitter with a half-life of $247 \mathrm{~d}$ ). Small amounts of other radioactive elements, such as cobalt $\left({ }^{60} \mathrm{Co}\right)$ and iron $\left({ }^{55} \mathrm{Fe}\right)$ were of less concern. The radioactive iodines decayed. The other radioactive elements, cesium and strontium, were found in low amounts mainly in the pandanus, coconuts, breadfruit, and arrowroot plants grown on the islands. Unexpectedly high levels of radioactive cesium and strontium were found in the coconut crab, a great delicacy to the Marshallese ( $n$ Rongelap they were temporarily banned from the diet). The doses from the above radioisotopes were not much different from the doses received by U.S. citizens (Conard et al. 1992).

A whole body counter of several tons was built and shipped to the Marshall Islands for determination of body burden of gamma emitters. In 1957, the Rongelap people were returned to Rongelap. Their body burden of ${ }^{137} \mathrm{Cs}$ on return was negligible. One year later the body burden was $25,000 \mathrm{~Bq}$, remaining at this level for about $2,500 \mathrm{~d}$ and then decreasing so that at $8,000 \mathrm{~d}$ after rehabitation it was $5,000 \mathrm{~Bq}$. By $9,800 \mathrm{~d}$ the level was about $500 \mathrm{~Bq}$.

\section{EPILOGUE}

There is a long, sad and tangled story of confusing top level management in the U.S. Government in which no one person or agency seemed willing to take the responsibility, finance, or assign authority for getting the job done. Most everything that Bugher had described in 1954 July resulted in confusion and failure to assign responsibility and arrange long term financing of the
Marshallese programs for which the U.S. was responsible.

After the initial examinations were completed, the AEC decided to move the Utirik people back to their home island since the low residual radiation levels were considered safe for habitation. In 1954, they were returned and provided with supplementary food. However, surveys of Rongelap Island showed that radiation levels were too high to permit the people to return. Therefore, they were moved to temporary quarters set up for them on a small island (Ejet) at Majuro Atoll several hundred miles south of Kwajalein. Following our initial examinations of the American servicemen, they were taken to Tripler Army Hospital in Honolulu for further examination by Army physicians. Lifetime studies were not initiated as recommended to the CJTF-7 and was suggested in the JTF Radiological Safety Volume 1 (Defense Nuclear Agency 1985).

The Utirik people also developed a few thyroid tumors. It is unclear whether this is a characteristic of the Pacific Islanders or was due to radioiodines. Studies continue on body burdens of radioisotopes considered in other presentations in this issue of Health Physics.

The displacement of the Bikinians resulted in a major change in lifestyle, diet, etc., which may have contributed to diabetes, its deleterious effects on health, etc., whereas the Bikinians and residents of other atolls have probably not been exposed to harmful levels of radiation. They have been subjected to major psychological trauma from repetitive relocation and are aptly called "nuclear nomads" by Weisgall (1994).

In 1985, the Rongelapese were removed from Rongelap to Kwajalein because they believed all of their health problems were due to radiation.

With transfer of responsibility for internal contamination the Medical Team was no longer responsible for the measurements of radioactivity in foodstuffs or body burdens.

\section{Summary}

1. The exposure of the Marshallese and the military personnel showed that fallout from a nuclear explosion may have major health effects.

2. In the case of Bravo short term effects were:

a. Nonfatal depression of blood cell production in Marshallese and Americans;

b. Skin burns from beta emitting fission products;

c. Measurable internal contamination of several fission products;

3. Longer term effects:

a. One case of acute myeloid leukemia;

b. Unexpected serious effects of radioiodine family on thyroid function.

1. Hypothyroidism children and adults

2. Cretinism: two boys

3. Thyroid tumors (benign and malignant)

Lifetime observation of Marshallese and military personnel was recommended. Military personnel were not followed for reasons not clear to us. 
Acknowledgments - This research was supported in part by Department of Energy under Contract DE-AC02-76CH00016.

\section{REFERENCES}

Conard, R. A.; Lowrey, A.; Eicher, M.; Thompson, K.; Scott, W. A. Aging studies in the Marshallese exposed to fallout in 1954. In: Lindop, P. J, Sacher, S. A., eds. Radiation and aging. London: Taylor and Francis; 1966: 345-360.

Conard, R. A.; Dobyas, B. M.; Sutow, W. W. Thyroid neoplasia as a late effect of active exposure to radioactive iodine in fallout. JAMA 214:316-324; 1970.

Conard, R. A.; Paglia, D. E.; Larsen, D. E.; Paglia D. E.; Larsen, P. R.; Sutow, W. W.; Dobyns, B. M.; Robbins, J.; Krotosky, W. A.; Field, J. B.; Rall, J. E.; Wolff, J. Review of medical findings in a Marshallese population 26 years after accidental exposure to radioactive fallout. Upton, NY: Brookhaven National Laboratory; BNL 51261; 1980.

Conard, R. A. Fallout: The experiences of a medical team in the case of Marshallese accidentally exposed to fallout radiation. Upton, NY: Brookhaven National Laboratory; Report No. 46444; 1992.

Cronkite, E. P.; Bond, V. P.; Conard, R. A.; Shulman, N. R.; Farr, R. S.; Cohn, S. H.; Dunham, C. L. Response of human beings accidentally exposed to significant fall-out radiation. JAMA 150:430:454; 1955.

Cronkite, E. P.; Bond V. P.; Dunham, C. L. Some effects of ionizing radiation on human beings: $A$ report on the Marshallese and Americans accidentally exposed to radia- tion from fallout and a discussion of radiation injury in the human being. Washington, DC: U.S. Atomic Energy Commission, 1956.

Cronkite, E. P.; Bond, V. P.; Conard, R. A. Medical effects of exposure of human beings to fallout radiation from a thermonuclear explosion. Stem Cells. 13:49-67; 1995.

Defense Nuclear Agency. Vol. 1. Radiological safety, Operation Castle Final report. Headquarters Joint Task Force Seven. Washington, DC: Defense Nuclear Agency; 1985.

Lessard, E.; Miltenberger, R.; Conard, R.; Musolino, S.; Naidu J.; Moorthy, A.; Schopfer, C. Thyroid absorbed dose for people at Rongelap, Sifo and Utirik. Upton, NY: Brookhaven National Laboratory; BNL 51882 UC-48, Bio Med TIC 5400; 1985.

Lisco, H.; Conard, R. A. Chromosome studies on Marshall Islanders exposed to fallout radiation. Science 157:445447; 1967.

Robbins, J.; Rall, J. E.; Conard, R. A. Late effects of radioiodine in fallout. Ann. Intern. Med. 66:1214-1242; 1967.

Sutow, W. W.; Conard, R. A. The effects of fallout radiation on Marshallese children in Radiation Biology of the foetal and juvenile mammal. Proceedings of the 9th Annual Hanford Biology Symposium. 1969.

Radiobiological assessment for resettlement of Rongelap in the Republic of the Marshall Islands. Washington, DC: National Academy of Sciences Press; 1994.

Weisgall, J. Operation Crossroads. Annapolis, MD: Naval Institute Press; 1994. 